\title{
State-Corporate Crime and the Process of Capital Accumulation: Mapping a Global Regime of Permission from Galicia to Morecambe Bay
}

\author{
Ignasi Bernat ${ }^{1} \cdot$ David Whyte ${ }^{2}$
}

Published online: 17 August 2016

(C) The Author(s) 2016. This article is published with open access at Springerlink.com

\begin{abstract}
This paper seeks to develop the principal concerns of the state-corporate crime literature by drawing connections between two incidents that occurred 15 months apart: the sinking of the oil tanker the Prestige in Galicia in November 2002 and the killing of 24 Chinese migrant workers at Morecambe Bay in the North West of England in February 2004. It begins by introducing the key features of the two cases, before exploring how they might be described and understood as state-corporate crimes. It then identifies a tendency within the literature to analyse state-corporate crimes as 'moments of rupture' in the regulatory relationship. Seeking to move beyond such 'moments of rupture', the paper argues for an understanding of regulatory relationships as part of a broader regime of permission that seeks the smooth and uninterrupted accumulation of capital. It thus identifies the 'process' that must be analysed as a process of capital accumulation. This process is illustrated by focussing on the spheres of production and distribution in this story of capital accumulation. In the course of describing the complex 'regime of permission', the paper uncovers a structure of impunity that generally enables the most powerful architects and beneficiaries of state-corporate crime to sustain a process of capital accumulation.
\end{abstract}

David Whyte

David.Whyte@liverpool.ac.uk

Ignasi Bernat

Ignasi.Bernat@udg.edu

1 Facultat de Dret, University of Girona, Campus de Montilivi, c/de la Universitat de Girona, 12, 17071 Girona, Catalunya, Spain

2 Department of Sociology, Social Policy and Criminology, University of Liverpool, Eleanor Rathbone Building, Bedford Street South, Liverpool L69 7ZA, UK 


\section{Introduction}

Studies in state-corporate crime, organised around a growing and relatively new agenda in corporate crime research, take the on-going and often symbiotic relationship between state/ public actors and private actors (normally large corporations) as the point of departure for its analysis (Kramer et al. 2002). There are three major challenges to criminology that this approach implies. First, by developing an analysis of power relations beyond the immediate circumstances of a particular moment, fixed in time, with very particular circumstances, it takes us beyond a paralysing fixation that mainstream criminology has with criminal 'events', a fixation that is of limited value because it does not allow us to view the conditions that produced those crimes as rooted in more on-going and ever-present social conditions of unequal power (Pearce 1976). The state-corporate crime literature thus points consistently to a structure of political economy which creates the particular conditions that shape the relationship between states and corporations (Kramer et al. 2002; Kramer and Michalowski 2006). In this sense, the literature seeks to develop an understanding of the social content of the relationship between states and corporations in modern liberal democracies. A similar critical observation is made consistently in feminist analyses of male violence; which is conceived of as a form of violence that can only be understood as part of an on-going state of gendered power relations (Walklate 2003: 127-129). Second, moving from event to process poses a difficulty for more statist or administrative criminological approaches, since it shifts the terrain on which we search for who might be held 'criminally' responsible. Third, this literature locates the production of crime in the structures of capitalism, not least in the drive for accumulation that shapes the relationship between states and corporations (the motivations for crimes the lack of control and regulatory structures and the relative impunity granted to corporate actors). The literature that points to 'empire crime' is particularly illuminating in this respect, highlighting as it does, the deep historical origins of state-corporate collusion (for example, Iadicola 2010; Iadicola 2011; see also, Kauzlarich and Matthews 2006).

We develop the latter point later in this paper, and argue that understanding statecorporate crime as part of a historically configured process of capital accumulation impels us to look beyond the actors and social relationships that are immediately visible in the circumstances of the 'crime' or 'event'.

The importance of understanding of state corporate crime as an historically and socially situated process is illustrated by our analysis of the sinking of the Prestige oil tanker in Galicia in November 2002 (an environmental catastrophe reportedly with greater economic and environmental costs than the Exxon Valdes spill; Carstens 2003) and the killing of 24 Chinese migrant workers at Morecambe Bay in the North West of England in February 2004 (the worst industrial multiple fatality in the UK since the Piper Alpha disaster). As we uncover the historically and socially situated immediate conditions of those cases, we argue that the Prestige disaster to some extent accounts for the conditions that produced the Morecambe Bay disaster (see, for example Bernat and Whyte 2015). We explain how we come to this conclusion in the discussion below, before returning to uncover the historical and broader social content of those 'events'.

\section{From Galicia to Morecambe Bay: Connecting Two Criminogenic 'Events'}

The sinking of the Prestige oil tanker in November 2002 created a spill that polluted thousands of kilometres of coastline and in terms of the ecological and economic damage suffered in the aftermath, was certainly the worst oil spill in Spain's history and perhaps 
the worst in Europe's history. The immediate crisis was immeasurably worsened by the Spanish government's order to tow the vessel out to sea, away from Spanish waters, despite warnings that the ship would not be able to withstand the storm conditions forecast for the area (Naucher 2013). In trying to remove the threat of both the environmental and political fall out from the spill, the Spanish government caused a further major rupture in the vessel and turned a manageable spill into the disaster of unmanageable proportions. Had it followed its own protocols set out in the Spanish National Emergency Plan, it would have towed the vessel into the port to deal with the spill (Greenpeace 2012). Ángel del Real, Maritime Captain of the port of La Coruña gave the order to tow the vessel $160 \mathrm{~km}$ from the coast escorted by the Spanish Navy. The decision was approved by the Minister for Development, and later by the Prime Minister José María Aznar. The ship owners and the company of the rescue opposed the decision to tow the vessel away from the coast. Moreover, it seems that the decision to change the direction of the vessel was also taken partly due to pressure from the French government (Catalán Deus 2003: 82).

Measured in terms of the impact on biodiversity and the environment, the collective cost of the catastrophe was huge. The 'black tide' was certainly the biggest ecological disaster to hit the Spanish coast, and was possibly the most damaging oil spill in European history. More than $2000 \mathrm{~km}$ of coast were affected. Shellfish, particularly mussels, were badly affected, as were other staple seafoods. For example, octopus catches fell by $50 \%$ in 2004 and 2005 in many areas. The Spanish Society of Ornithology estimated the number of sea birds deaths caused by the oil at between 115,000 and 230,000, one of the highest sea bird mortalities by non-natural causes ever seen (Ecologistas en Acción 2012). These are aspects of the consequences of the disaster, related to the loss of biodiversity, that are difficult to translate into monetary terms (Prada et al. 2002). At the same time, the cleaning and the restoration are collective costs that are measurable in monetary terms. The cost of the post-disaster clean-up was estimated at around 107 million euros. ${ }^{1}$ The most affected people were relatively low paid workers in the fishing and seafood industry. The impact on those sectors can be calculated according to the transformations in quantity and quality of the goods and services offered in the market (Varela Lafuente et al. 2003: 139). In 2003, the value of fishing and tourism lost totalled around 1.4 billion euros (ibid.: 148). The effects of the disaster are aggravated due to Galicia's status as one of the poorest areas in Spain together with its dependence on natural marine resources (Surís and Garza 2003: 317).

The circumstances of this tragedy seem rather distant from the Morecambe Bay disaster. Yet, both tragedies can be understood as part of the same complex chain of events. It is a chain that is connected by the dramatic impact upon market conditions precipitated by the Prestige disaster. One consequence of the Prestige disaster was the banning of all fishing and shellfish harvesting along the Western and Northern coasts of Spain. The ban, combined with what was generally a poor harvest year in Europe, intensified demand for a number of seafoods, including cockles. This intensification of demand led to pressure on other areas of shellfish production to maximise production in order to meet the demand. One of those areas was the west coast of Britain. In April 2002, it was reported that the price of cockles in the UK had soared from $£ 200$ per tonne in 2000 to $£ 2000$ per tonne in the months prior to the disaster (The Independent, 29th April, 2002; The Guardian 7th February 2004). The period between 2003 and 2004 was exceptionally good period for the cockle harvest in Morecambe Bay, making a significant increase in production possible. High prices were sustained over the next 2-3 years following the closure of the Galician

\footnotetext{
${ }^{1}$ Figures taken from eldiario.es, October 2014, available online http://www.eldiario.es/temas/prestige.
} 
cockling sites. In late 2004, 9 months after the disaster local newspapers in the North West of England were reporting the need for more migrant cocklers to meet a sustained demand.

On 5th February 2004, 23 cockle pickers were drowned at Morecambe Bay on the English Lancashire coast. The dead were immigrant workers from China who had been put to work on the cockle beds of the Fylde coast. The tides at Morecambe Bay are notoriously quick and the area was known for its difficult currents and quick-sands. On the day of the disaster, the tide times allowed for only $3 \mathrm{~h}$ of work before dusk, and the cockle pickers had begun work just as daylight was fading. The fact that the cockle pickers were working under highly dangerous conditions was largely due to the intensification of global demand for cockles.

Following the disaster, major questions were asked about the negligence of the British state. Several clear warnings about the possibility of fatalities occurring at Morecambe Bay had gone unheeded. In June 2003, the local MP Geraldine Smith had written to the Home Office with concerns that inexperienced Chinese cocklers were being employed on a fifth of the wages of British workers and that the conditions that they worked under were more acutely dangerous than the conditions faced by their British counterparts. A rescue of 40 workers from the sands occurred just 6 weeks before the disaster had been reported, yet no action was taken in response (Liverpool Daily Post, 7th December 2005).

Because we can identify a role played by the state in either producing or failing to prevent what happened in Galicia and in Morecambe Bay harms, they begin to look like archetypal state-corporate crimes. That is, they appear to fit closely with a standard definition of state-corporate crime as "illegal or socially injurious actions that result from a mutually reinforcing interaction" between state and corporation (Kramer and Michalowski 2006: 20). It is this focus on the "mutually reinforcing interaction" between state and corporation that is the point of departure for our discussion in the following section.

\section{Beyond State-Corporate Antagonism}

Generally, when we analyse problems of regulation, we impelled to look for a breakdown in the relationship between two, potentially antagonistic, parties (the state and the corporation). Yet, as the literature on state-corporate crime illustrates clearly, often there no clear antagonism or opposition of interest in those relationships, since those crimes often occur as a result of commonly shared or mutual goals (Kramer 1992; Aulette and Michalowski 1993; Kramer et al. 2002).

The state-corporate crime framework advances this approach by identifying two types of institutional relationships: those that are state-facilitated and those that state-initiated (Kramer et al. 2002; Bruce and Becker 2007). It is this duality that the literature uses to explore the full complexity of state involvement in, and contribution to, the circumstances that lead to corporate crimes. In the former type state-corporate crimes are the result of negligence or inactivity on the part of the states or their regulatory agencies in ways that collusively facilitate corporations in the commission of state-corporate crime. Thus, the state fails to provide the necessary mechanism to effectively balance or control the corporate activity. Often, a concept of "nested contexts" is introduced to show there is always a political economy that shapes the conditions for state-corporate facilitated crime, particularly when failures of regulation are discussed (Kramer 1992; Aulette and Michalowski 1993; Matthews and Kauzlarich 2000; Cruciotti and Matthews 2006). In the case of the latter-state initiated crime-state institutions pursue pro-active strategies that play a 
leading role in the commission of state-corporate crimes. Here, the state not only fails to regulate the private sector, but it has a paramount role in fostering the criminal activity that benefits corporations (see, for example, Rothe 2006; Whyte 2007).

At the global level, international financial institutions such as the World Bank or the International Monetary Fund can play the same role as public institutions or nation-states in facilitating or initiating corporate crimes (Friedrichs and Friedrichs 2002; Wonders and Danner 2006). A variation in the literature points to corporate-facilitated and corporateinitiated state crimes, a modification which foregrounds the agency of the corporation and the primary casual nature of capital accumulation in state-corporate crimes (Matthews 2006; Whyte 2009; Lasslett 2014).

The state-corporate crime approach has been subject to some critique on the basis that it does not go far enough in revealing the social content of state corporate crimes. As Tombs (2012) has argued, for example, the state-corporate crime literature retains a tendency to focus upon the immediate circumstances of:

discrete joint ventures between corporations and states, either at specific moments or towards specific ends, thus abstracting these from a more generalized set of social relationships, which are on-going, enduring and more akin, in fact, to a process.

Similarly, Lasslett (2010: 212) has noted that this literature is characterised by its inability to concretise state-corporate crimes as part of a broader system of production and "orient the researcher to less evident, but extremely important social realities that inform the crimes of the powerful."

We would agree with both Tombs and Lasslett. The description of our cases above provides the basis for launching an exploration of state-corporate crimes as events that are produced as part both of a more generalized set of social relationships, and a broader system of economic production. We say this because the most apparent link across those cases seems to be that they are "crimes of the economy" (Ruggiero 2013) in the sense that their circumstances are rooted in a classical political economy understanding of the human consequences of shifts in the forces of supply and demand that are shaped and co-ordinated in a global economy. The abstraction that both Tombs (2012) and Lasslett (2010) point to in their critique of state-corporate crime, however, is something that occurs outside the observable features of political economy. They are concerned with the way that particular approaches to political economy produce an abstraction of social relationships.

In order to deepen their critique-and to begin to see how we might make social relationships more concrete in the analysis of state-corporate crimes-we argue that much of the scholarship in what Lasslett (ibid.) calls orthodox studies of crimes of the powerful tends to develop its analysis around a particular flaw or problem in the institutional relationship between the 'state' and the 'corporation', or what we call in the discussion that follows, a regulatory pathology. Indeed, it is this understanding of the regulatory process that constitutes a primary example of the tendency to abstract social relationships that those previous critiques have identified.

\section{From Regulatory Pathology to the Regime of Permission}

The state-corporate crime literature has produced significant analyses of the subject of this paper: oil spills.

Bradshaw's (2014) discussion of the criminogenic structure of the industry represents a development of the conceptualisation of state-corporate crime by introducing the concept 
of 'industry' level to those of 'institutional', 'organizational' and 'interactional' levels that were firstly advanced by Kramer et al. (2002). Thus, the article points to the competition between business organizations that lead to more "criminogenic industry structures" ( $p$. 380), showing how governmental regulatory processes shape patterns of state-corporate harm. What is more, Bradshaw signals the role of the state apparatuses in fostering markets in the industry.

In this vein, Cruciotti and Mathews' (2006) article on the context that produced the Exxon Valdez spill highlights the importance of "a complex series of interactions between social actors" (p. 149). The paper, following Aulette and Michalowski (1993), argues that the "nested contexts" made this crime inevitable; that is, that societal, political and regulatory contexts established the basis for the crime to happen. The state-corporate crime occurred, the authors say, as a result of the profit motive intersecting with a lax regulatory environment. Thus, we are encouraged not to see these events as 'accidents', but as the result of a series of practices engaged in by a range of relevant actors. But what is interesting in this chapter is that the authors go way beyond their conclusion that the disaster resulted from the "wrongful intersections of government and business." In doing so, they point to a more historically and socially complex set of circumstances, including: the way that automation had led to fundamental changes in the labour process; the origins of Alaskan state government in the 19th century Gold Rush; and the emergence of a political economy of speed following the discovery of oil in 1968 and the OPEC embargo of 1973. Thus, the chapter actually goes much further in its analysis than simply elucidating some "wrongful intersections", but develops a complex and historically situated political economy. The paper in fact exposes a set of circumstance that are neither related to: (a) the failure of government in fulfilling its in vigilando role; nor (b) practices that were clearly initiated by the government authorities involved in taking decisions that led to the disaster. The paper shows how both those 'state-initiated' and 'state-facilitated' features were shaped by a deeper political economy of oil production.

Indeed, neither Bradshaw nor Cruciotti and Mathews' cases appear to us to be merely illustrating deviant state practices-rather they illustrate practices that are constructed within those states as normal and acceptable. Of course, the particular events that occurred can be understood as both deviant, and in any interpretation of those terms, their effects are criminogenic. But, the circumstances that led to the events cannot be regarded as deviant practices. As Bradshaw indicates, the political economy of hydrocarbon production is rooted in a much greater human catastrophe — climate change - and yet this is constructed only as deviant when a major event like the Gulf of Mexico spill occurs. Likewise, as we have indicated, Cruciotti and Mathews' discussion of the Exxon Valdes case is rooted in a 'normal' political economy of hydrocarbon production that produces 'deviant' outcomes. The implication of what we are arguing here is that the state-corporate crime approach usefully draws attention to some kind of constitutional flaw, or moment of rupture in the relationship between public (state) institutions and private (corporate) institutions. It is this tendency in the literature to focus upon what might be called moments of rupture in the constitutional public/private relation that leads us to analyse state-corporate crimes in a particular way, impelling us to look at immediately apparent empirical conditions where public authorities have either colluded in ways that breach the normal constraints of their 'public' role, or have failed to protect us, the public, from the harmful activities of the private (corporate) sector (Whyte 2014).

In this sense, we are arguing that state-corporate crime should not be pathologised. That is to say that state-corporate crimes are not necessarily accurately described as "wrongful interactions" because they are not necessarily deviations from a normal social path or 
social state in which a 'better' relationship between government and corporation can guarantee protection from the process of capital accumulation. Rather, corporate crimes are better understood as interruptions or unplanned phenomena that arise from the normal conditions of doing business. As this article will argue, in order to fully understand the formative conditions of state-corporate crime, it is not enough to look to regulatory pathologies; it is not enough to limit our analysis to the empirical conditions of regulatory 'collusion' and 'failure'.

How, then, could we think about the deeper architecture of corporate power in order to take us beyond the immediately observable conditions of those regulatory pathologies? We approach corporate crime and its regulation as a distillation of a range of social relationships, institutions and practices that exist prior to the immediately observable conditions and relationships that produced the criminal event. In doing so, this shifts our focus away from the moment of rupture towards a concern with recovering the social content and the historical context of those immediately observable relationships.

We therefore note at this stage something that none of the state-corporate crime scholars we cite would disagree with: that states or governments do not merely facilitate or initiate criminal and harmful practices. Rather, capitalist states produce the entirety of the social conditions that enable criminal and harmful practices to occur. In capitalist social orders, states play a creative and enabling role for regimes of capital accumulation; corporations are the key institutions in realising capital accumulation. Governments establish the juridical and administrative framework for corporations, transport and communication infrastructures, and organise diplomatic relationships with states to enhance opportunities for import, export and investment and so on. States help to constitute capital, commodity, commercial and residential property markets; help to produce different kinds of 'human capital'; constitute labour markets; regulate the employment contract; constitute corporations through the rules that permit particular forms of ownership; specify the rules of corporate liability and so on (Tombs and Whyte 2015).

The corporation, in the sense that it is established formally, is permitted through its legal and political status to structure its activities in particular ways. Those include: its ability to trade as a separate entity; its ability to structure ownership in particular ways, its ability to attract investment through a range of incentives and so on. Those privileges are generally guaranteed by the rules of incorporation in a given national state. Corporations are normally registered by the state for commercial purposes and are granted a legal identity. This legal identity enables corporations to exist as an entity wholly separate from the individual identities of its owners or stockholders. It is this identity that enables corporations to assume a status as holder of particular rights, to own property and to exploit particular privileges such as 'limited liability'. As part of this process of incorporation, companies are permitted to establish complex ownership chains in which their operations are spread across a number of formally separate companies.

By foregrounding this deeper, constitutional, relationship, we are beginning to probe the a priori-historically constituted-architecture of state-corporate power as part of what Tombs calls "a more generalized set of social relationships". In this sense, we are seeking to conceretise, following Lasslett, the "a broader system of production", which in capitalist social orders, is organised around a process of capital accumulation. In order to do so, we see the observable institutional relationship between 'state' and 'capital' as merely an epiphenomena of a broader regime of permission, and therefore an epiphenomena of how capital accumulation is more generally reproduced through regulatory structures. It is this understanding that can more fully illuminate the social content of corporate crimes. And it is to this task that the rest of the paper turns. 


\section{The Regime of Permission from Galicia to Morecambe Bay}

Here we specify the regulatory process - or the regime of permission-that enables capital accumulation to be reproduced. This is how we begin to discover the entirety of the social conditions that enable criminal and harmful practices to occur.

The broader regime of permission that we point to can be usefully delineated into four major spheres, the categories that Marx called the 'moments' of capital accumulation: the spheres of production, distribution, exchange and consumption (Marx 1993). He argues that since production is the predominant sphere, the latter categories of distribution, exchange and consumption merely represent different stages or 'moments' in the life of a product. However, the three other spheres also determine the form that production takes (ibid.). In this analysis we are largely concerned with the social content of the spheres of production and distribution because this is most clearly where we can observe the regime of permission in our cases. It is clear that there is a lot to be said about how the events that we describe here have impacted upon exchange and consumption, not least how the profound reshaping of seafood markets and the fluctuation of seafood prices in the wake of the Prestige undoubtedly had socially harmful effects (for example in the emergence of intensified demand, a decline in the quality of food products and so on). Whilst this is beyond the scope of this paper, we would therefore stress that there is much to be learned from a fuller analysis of the spheres of exchange and consumption as part of the totality of the regime of permission.

Our priority here, however, is to see a little more clearly how both the Prestige and the Morecambe Bay disaster were made possible through a set of a priori social relationships that in each of those spheres of production and distribution are reproduced. By doing so, we uncover a highly complex regime of permission, a core part of which materialises in each case as a structure of impunity. Though this analysis we can see precisely how the major players are the architects and key beneficiaries of each 'crime', but in its aftermath are permitted to continue as if nothing had happened.

Although our case is largely a case of oil distribution, we offer our first set of observations, on the sphere of oil production, as context for understanding the social content of our case.

\section{Oil Production}

The regulatory practices that govern the production of oil are based upon one over-riding principle: the permission to continue the extraction of oil at the most profitable rate of production. The regulation of oil production is highly regulated in this sense by oil producing states. The US, as the major oil producing nation, controlled oil prices for the early half of the 20th century, ceding its influence to the OPEC countries in the $1970 \mathrm{~s}$. The current global dip in the price of oil is a result of the weakening of this system of production controls in the OPEC oil producing countries and a re-shifting of the balance back to Western producers (Harvey 2010; Arrighi 1999).

The sphere of exchange comes to life here since the regulation of production in oil markets is concerned largely with price regulation. Of course, there are a complexity of social and environmental regulatory structures that, for example, aim to mitigate spills and impose particular safety protections for workers. Those standards apply differently across jurisdictions. However, although they may impact on the conditions of production, those forms of regulation are not concerned with limiting the volume of production per se, but 
with minor adjustments to the way that oil is produced. Environmental controls are also imposed after the production process: at the stage that the product is used. Thus, emissions controls on industry or on the use of road vehicles seek to limit use at the point of consumption. Climate change treaties or international agreements that seek to mitigate the impact of the use of hydrocarbon fuels seek to limit carbon emissions. If there is a rudimentary system of regulation set out in agreements such as the Kyoto protocol, it is one that seeks to regulate the end point of the production cycle, rather than control the level of extraction per se. Whilst our very truncated and selective over view of some key of dynamics in the regulation of oil production may not seem empirically relevant to what follows (and we note at this stage the origin of the heavy fuel being transported by the Prestige is not known) we have in this section identified a core principle of regulation: a clear regime of permission principle at work, in which the potential harms of hydrocarbon production are subordinated to the production process itself. This is the broader regime of permission that frames our discussion here: one that sets the coordinates for understanding the principle on which the distribution of oil proceeds.

\section{Oil Distribution}

The regime of permission that is significant in the distribution of oil by sea is notoriously complex and fragmented. Each nation state has its own regulatory structure for merchant shipping. At the same time, there is an international treaty structure and a number of international organisations responsible for regulation. A UN organisation, the International Maritime Organisation (IMO) is responsible for developing and maintaining safety, environmental protection, and security issues relating to shipping. IMO regulations on the transportation of oil cover a range of issues including the technical specifications applying to ballast and stability, the location of oil storage on ships, the hull structure (single hull tankers are being phased out as a result of IMO double hull regulations), and the rules for assessing risk and reporting requirements. In this industry, a very specific process of regulating the ownership of vessels is organised under a system commonly known as using a 'flag of convenience' or 'open register'. Employment practices in shipping are governed by other sets of regulations, namely the standards set by another UN organisation, the International Labour Organisation.

However, a system of 'flags of convenience' generally enables national regulations to be flouted in marine employment. This basically means that a vessel can be registered in a different national state than the ship's owners under a 'flag of convenience' or 'open register'. Owners' reasons for opting for an open register are many and varied and may include secrecy, tax avoidance, and avoiding national labour or environmental regulations. Flags of convenience therefore make it difficult to obtain any detailed information about the company. In the case of the Prestige, the device of open registration served the owners well.

As Hansen's (2008) forensic analysis shows, the company that owned the Prestige, Mare Shipping, was registered in Liberia, a flag of convenience jurisdiction. The oil tanker was chartered by a Swiss company, Crown Resources, also the owner of the cargo who set it on course for Gibraltar where it was to wait for new instructions. Crown Resources itself was owned by a holding company based in Luxemburg, which in turn was owned by another holding company, based in Gibraltar, in turn owned by third company based in Liechtenstein. The third holding company was owned by Alpha Group, one of Russia's largest investment fund groups that has major interests in commercial and investment banking, asset management, insurance, retail trade, water utilities, and a wide range of 
other investments. Alpha Group is therefore the real owner of the oil carried by the Prestige. Using different companies located in several jurisdictions made the attribution of liability difficult. The countries outside Russia involved in this secondary chain of ownership (Luxembourg, Gibraltar and Liechtenstein) are all tax havens, and are known for the protection of commercial secrecy. This ownership chain, involving three different secrecy jurisdictions, made it difficult to obtain reliable information on the circumstances leading to the disaster. It is this complexity of the ownership chain that also minimized financial and reputation damages to the ultimate owners, Alpha Group. Following the disaster, the various assets of Crown Resources were sold off in separate parts, and then reconstructed around new enterprises, 'Energy Resources' and 'Commodities Trading Company' both based in Switzerland. This strategy enabled the real owners to further distance themselves from the Prestige disaster and to avoid accusations of wrongdoing, as well as continue trading in exactly the same way as before (Catalán Deus 2003: 224-225).

It took 14 years before a judgment in the Spanish Supreme Court in January ruled that Mare Shipping, along with the ship's insurer were jointly liable for the spill (Spain. Supreme Court 11/2016). It remains to be seen if there will be any action to recover the damages. However, even if damages were sought, because they are owners of incorporated businesses, it is highly unlikely that the individual owners of those companies will be required to pay full costs of the disaster.

Instead, criminal responsibility has been focussed on the individuals involved in the immediate circumstances of the disaster. A similar observation, as we shall see later in this paper, can be made about the Morecambe Bay disaster. The criminal trial of three men, the captain, the chief engineer and the Spanish government's General Director of Marine Affairs, López Sors, began in Spain in November 2012 in the Audiencia Provincial de La Coruña, and was finally confirmed in the Spanish Supreme Court case in January 2016 noted above. The court delivered its sentence 1 year later, 11 years after the disaster. The captain had been found guilty in an earlier case and sentenced to 2 years in prison (serving 9 months of the sentence). Only the captain was found guilty of crimes against the environment. López Sors, the only representative of the Spanish government to be indicted was acquitted, even though the government's negligence was clear: a Governing Committee was never constituted, no qualified personnel were sent to the ship, and the ship was knowingly sent into a storm and then ordered to change the direction several times, making a spill inevitable. Thus, the judgement against the captain effectively absolved both the government its responsibility for managing the crisis along with the owners of the oil and the vessel (Naucher 2013).

What we have described here is a series of complex regulatory mechanisms that originate in the process of capital accumulation, and in the way that a particular form of property ownership (the corporation) is reproduced in regulations that are universally applied across capitalist states. Those mechanisms have reproduced a structure of impunity that enabled both the owners of the vessel and the oil to escape liability for the disaster. A crucial aspect of regimes of permission, is, in other words, revealed clearly here as a complex structure of impunity.

This structure of impunity extended to the US regulator. In a failed attempt to obtain compensation for the disaster (El País, 9th June, 2008), the Spanish government, instead of pursuing Mares Shipping or the Alpha Group, which would have proved difficult for reasons set out in the preceding discussion, attempted to prosecute the regulator that permitted the Prestige to operate, the American Bureau of Shipping (ABS). In this case, the US courts ruled that Spain could not prove that the actions of ABS constituted a cause of the wreck of the Prestige. Spain made several arguments in the case. The first related to the 
failure to ensure compliance of standards relating to the inspection of condition of the vessel. After the Erika disaster off the coast of France in 1999, the ABS proposed that major classification organisations must adopt a number of measures, including classifying old tanks, organising annual inspections, and the mandatory use of the SafeHull program. ABS had been accused of failing to act on knowledge of structural damage to the hull of the Prestige that it had possessed since 1996 (ibid.; Reino de España v. American Bureau of Shipping). The court found that although the regulations were not followed in the case of the Prestige, they were not mandatory at the moment of the wreck and thus ABS was not liable.

The Prestige was inspected but remarkably, the results of the Marine Services inspection were not reported because the Crown Resources did not pay the fee that was due for the full inspection program. This is remarkable, because the condition of the vessel was hidden simply because the Prestige's charterer had refused to pay a statutory fee. Because of this and ABS's failure to share the information of the previous tests with local surveyors, Spain alleged that ABS was reckless. Spain additionally suggested that ABS was reckless as the Prestige's then Captain Kostazos sent a fax to Marine Services in August 2002 alerting the regulator of the serious condition of the Prestige and asking for an emergency inspection. According to the American court that since ABS was a parent company, then it could not be held liable for the knowledge held by its subsidiary company. Spain could not prove that Marine Service ever informed ABS, or that ABS was aware of the issue; or even that the fax arrived to its destination. Thus, the court dismissed the Spanish petition and decided that ABS had no legal responsibility for the condition of the Prestige (Reino de España v. American Bureau of Shipping). The latter finding is particularly instructive, since we can discern a principle of outsourcing within the administration of the US regulatory system itself (Hansen 2008). It is this principle of outsourcing that enabled the regulator-as well as the owners of the vessel and the oil to escape liability!

In sum, this structure of impunity ultimately ensured the status quo: the commercial strength of the corporate owners of the oil was maintained; the system of shipping regulation and of oil distribution remained unchallenged; and crucially, the pattern of ownership was undisrupted. Those different forms of impunity, drawing upon a myriad of different legal structures and different institutional forms converge as part of the general regime of permission.

\section{Seafood Production}

The production of seafood is, in general terms, regulated in ways that seeks to limit its environmental impacts at the point of production and to ensure a stable and sustainable fishing industry. This is not to say various international mechanisms have been successful in meeting this aim, but social protection is at least one of the stated aims of such regulatory policies. International fishing limits, such as those imposed by the European Union are aimed at precisely this form of control (Pearse and Walters 1992). The closure of the fishing grounds by the Spanish government following the Prestige disaster was done ostensibly to protect human health, but also to enable fish stocks to recover and be replenished. As we have seen, one of the effects of this ultimately was to create a new set of risks to the safety of workers in UK shellfish production.

In times of shortage or environmental disaster, production controls on cockle picking in Morecambe Bay are similarly imposed by a statutory government agency. The regulator currently empowered to do this notes that its formal aim in law is to secure "the right balance between social, environmental and economic benefits to ensure healthy seas, 
sustainable fisheries and a viable industry."2 At the time of the Morecambe Bay disaster, stocks were healthy, and therefore did not require such controls.

Labour conditions in the production of seafood in the UK are the responsibility of a range of agencies. Foremost amongst those is the Health and Safety Executive, responsible for enforcing safety standards that are designed to protect workers across the seafood production sites that are the concern of this paper. In practice, however, in the context of the regulation of the undocumented labour market that the Morecambe Bay cockle pickers were part of, the regulatory authorities have neither the resources nor the political will to inspect and investigate unregistered enterprises and seek compliance or take enforcement action in this sector. In any case workplace safety regulators are operating in an environment that is dominated by immigration control. In the months and weeks leading up to disaster, cocklers on Morecambe Bay might have had a chance of seeing immigration officers, but would have had little chance of seeing workplace safety regulators (for example, The Daily Mail, 23rd August, 2003). Certainly the level of state effort directed at controlling 'illegal' workers dwarfs the state effort that seeks to ameliorate the conditions that enable migrant workers to be exploited (Burnett and Whyte 2010).

Indeed, it is in this context that we must understand the prosecution of the Chinese 'gangmaster' who employed the cockle pickers. In March 2006, Lin Liang Ren was convicted for the manslaughter of 21 cockle pickers (by the time of the court case, two of the bodies had not recovered from the sea) and given a 14 year jail sentence. Two others involved in their employment, Zhao Xiao Qing and Lin Mu Yong were also convicted of facilitating contraventions of immigration law. They were sentenced to 2 years and 9 months, and 4 years and 9 months respectively. The two owners of the Liverpool Bay Fishing company that bought the cockles from Lin to sell on to larger producers were cleared of facilitating the crime. All of the larger market players: the canning factories, the exporters and the corporations marketing and selling the cockles were sufficiently distanced by the supply chain to prevent them from even being questioned in public discussion about their role in the deaths of the 24 workers. The role of those players is discussed briefly in the section that follows.

\section{Seafood Distribution}

Responsibility for seafood distribution is similarly spread across a complex chain of different entities. A large part of the global demand for shellfish is driven by Spanish consumers. Indeed, the Spanish market is certainly the most important market for cockles in Europe, buying most of its cockles from European countries. This market had previously been supplied mainly from Galicia (Pawiro 2010). Recognising the opportunities in Britain, some of the Spanish companies moved into buy cockles from producers they have not dealt with before. One indication of this entry into the market by big Spanish players illustrated when in 2002 the Spanish company Conservas Dani bought a family-run firm based in Wales which had previously preferred to deal with established cocklers (Herbert and Nash 2004). The net effect of the entry into the market of the large Spanish market players was therefore that pre-existing supply chains were re-configured.

The intensification of market conditions had some very direct impacts on labour conditions. An ongoing dispute between British and Chinese gangs of cocklers intensified

\footnotetext{
${ }^{2}$ North Western Inshore Fisheries And Conservation Authority Constitution March 2013, online at: http:// www.nw-ifca.gov.uk/contents/images/NWIFCA\%20Constitution\%20March\%202013\%20\%28Final\%29.pdf, viewed 6th April, 2016.
} 
during the months and weeks leading up to the disaster. The dispute was partly about the territorial rights to work the Bay, but was also fuelled by the assumption that Chinese labourers were gaining a competitive advantage because they were more likely to take risks than locally established cocklers. In the week before the disaster, buyers were being asked by British cocklers not to purchase cockles harvested by Chinese gangs (ibid.). However, the reconfiguration of trading relationships in the industry most probably made it easier for new sellers of British-harvested cockles to enter the market. Indeed, it was reported in court that the Liverpool Bay Fishing Company that was buying the cockles from the direct employer of the 24 workers was selling to the large Spanish market players (Daily Post, 20th September 2005). If the shift in conditions of the normal sites of shellfish production in Europe intensified demand for production in Britain, the restructuring of ownership patterns in the industry thus led to the repositioning of trading relationships in the industry. Those changes in economic relationships combined to create new opportunities for gangmasters employing Chinese workers to enter those markets.

In the aftermath of Morecambe Bay, none of the key players in the labour market described above were even questioned, never mind investigated for their role in creating the conditions of the crime. In many ways this is a very obvious point, for the structure of regulation in both the seafood and labour markets, and the regulatory regimes that governed those markets, enable the most powerful players to remain distant from the conditions of exploitation that they benefit from. In this context it almost seems ludicrous to question why they were not prosecuted. How could the most powerful players - the buyers of the cockles that operated several stages along the supply chain from the point of production-possibly be questioned when the likely destination of the cockles-and the source of the demand-was masked by the same complex supply chain?

The production and distribution of oil and seafood, though organised in different geographical and regulatory spaces, are organised using the same principles. There is a principle of outsourcing and fragmented structure of ownership across production and distribution in both industries. It is this organised fragmentation that guarantees a number of crucial outcomes: cost reduction, labour casualization and ultimately distancing the most powerful players from the entry-end of the supply chain. A complex regime of permission thus provides the foundations for capital accumulation before it establishes regulatory protections for the environment or workers.

\section{Conclusion}

Systematically drawing the connections across two connected 'events' reinforces the problems we face in focussing on immediately perceived criminal practices. Both are disasters that must be understood as part of what Ruggiero (2013) has called the collateral damage of the market. So both disasters are linked in this broad sense. Making those connections also demonstrates more specifically the inadequacies of a pre-occupation with either the moment of 'failure' of the state to regulate or control (and the state-corporate crime literature very often points to such moments of failure), or with the moments at which we can identify visible collusion between states and corporations.

The state-corporate crimes described here can not be explained by a breakdown in the regulatory function of the state; they occurred not because the state was disobeyed, but either because the state was obeyed, or merely because it upheld a pattern of social relations-embedded in particular social and economic practices-that has existed form many decades. In neither case were the formative conditions of the criminogenic 'event' 
found in particular decisions and actions or non-decisions and inactions of state or government institutions. There were elements we could describe as state initiated or state facilitated, but those conditions don't fully describe those state-corporate crimes.

The circumstances that led to the Prestige and Morecambe Bay disasters can therefore only be partially explained using a concept of state-corporate crime. The corporate crimes we describe here emanate from an architecture of power in which states guarantee corporations various privileges and infrastructural capacities. As we have noted in some detail here, the Prestige crisis was certainly aggravated as a consequence of the negligence of the US regulators, and the international systems of regulation. In this sense, some elements of the Prestige can easily be described as state-facilitated. But what was facilitated here? It makes little sense to describe the immediate circumstances in those terms, since the US state had no direct stake in the structure of profit or ownership in this case. Rather, it had a stake in a global regime of permission that enables capital accumulation from oil markets generally. The Spanish state similarly benefits from this regime of permission.

The response of the Spanish state to the disaster indicates the complexity of tracing any common goal here. After all, the Spanish government clearly attributed the problem of regulation to the US state, as is indicated by its attempt to sue ABS. This complexity is also illustrated also by the immediate response of the Spanish government in the ordering of the vessel to be towed out to sea away from Spanish waters, an order that was strongly resisted by the ship's owners. Again, if there is a common goal, it is not clear in relation to the immediate circumstances of the disaster, but at a very general level in the global regime of permission.

It is a process of capital accumulation that is guaranteed and under-pinned at every turn by this complex regime of permission. And this process of capital accumulation reveals much about the real structure of social relations. The workers at Morecambe Bay died producing value for corporate players from a commodity that at some time in the past was a common resource. Their position was made more vulnerable by the commodified distribution of another common resource, oil.

If the social relations of expropriation and exploitation that created the Prestige and Morecambe Bay disasters are to be fundamentally challenged, then we must contemplate something more profound that a shift in the relationship between the state and the corporation. We must contemplate how we can sustainably manage common resources for the common good. Clearly this is not possible under a capitalist regime of permission. We must therefore begin to explore exactly how we can manage those resources under a different system of social relations, one in which corporations are no longer permitted to function in the way they currently are. And to do so we need to think about how social relationship should be altered not merely in the conditions that we find in the moments of rupture, but in the social relations that are deeply conditioned in moments of production, distribution, exchange and consumption.

Open Access This article is distributed under the terms of the Creative Commons Attribution 4.0 International License (http://creativecommons.org/licenses/by/4.0/), which permits unrestricted use, distribution, and reproduction in any medium, provided you give appropriate credit to the original author(s) and the source, provide a link to the Creative Commons license, and indicate if changes were made. 


\section{References}

Arrighi, G. (1999). The long twentieth century. London: Verso.

Aulette, J., \& Michalowski, R. (1993). The imperial chicken fire: States, corporations, and public health. In K. Tunnell (Ed.), Political crime in contemporary America. New York: Garland Press.

Bernat, I., \& Whyte, D. (2015). Entendiendo los Orígenes del Crimen Estatal-Corporativo: un análisis de los desastres del Prestige y Morecambe Bay. Revista Crítica Penal y Poder, no. 9, September, pp. 255-278.

Bradshaw, E. (2014). State-corporate environmental cover-up: The response to the 2010 Gulf of Mexico oil spill. State Crime Journal, 3(2), 163-181.

Bruce, A., \& Becker, P. (2007). State-corporate crime and the Paducah Gaseous Diffusion Plant. Western Criminology Review, 8(2), 29-43.

Burnett, J., \& Whyte, D. (2010). Wages of Fear. Leeds and Liverpool: PAFRAS and University of Liverpool.

Carstens, K. (2003). Ready (or not) for oil spills-EU waters mapped for risk. Politico.eu. 17th September.

Catalán Deus, G. (2003). DesPrestige: el ocaso del Partido Popular ante la mayor catástrofe ambiental en España. Madrid: La Esfera.

Crucciotti, T., \& Matthews, R. (2006). The Exxon Valdez oil spill. In R. Michalowski \& R. Kramer (Eds.), State-corporate crime: Wrongdoing at the intersection of business and government. New Brunswick: Rutgers.

Ecologistas en Acción. (2012). ¿Nunca más? Una catástrofe como la del Prestige puede volver a ocurrir. Los problemas de una sociedad adicta al petróleo. www.ecologistasenaccion.org.

Friedrichs, D., \& Friedrichs, J. (2002). The World Bank and the crimes of globalization: A case study. Social Justice, 29(1-2), 13-36.

Greenpeace. (2012). Otro Prestige es Posible. Reflexiones para evitar otra marea negra. www.greenpeace.es.

Hansen, R. (2008). Multinational enterprise pursuit of minimized liability: Law, international business theory and the prestige oil spill. Berkeley Journal of International Law, 28(2), 410-451.

Harvey, D. (2010). The Enigma of capital and the crisis of capitalism. New York: Oxford.

Herbert, I., \& Nash, E. (2004). How Spain's insatiable appetite fuels a desperate pursuit of cockles in Morecambe. The independent on sunday, 15th February 2004.

Iadicola, P. (2010). Controlling crimes of empire. Social Justice, 36(3), 98-110.

Iadicola, P. (2011). Do empires commit state crime? In D. Rothe \& C. Mullins (Eds.), State crime: Current perspectives. New Brunswick: Rutgers.

Kramer, R. C. (1992). The space shuttle challenger explosion: A case study of state-corporate crime. In K. Schelgel \& D. Weisburd (Eds.), White collar crime reconsidered, pp. 212-241. Boston: Northeastern University Press.

Kramer, R., \& Michalowski, R. (2006). The invasion of Iraq. In R. Michalowski \& R. Kramer (Eds.), Statecorporate crime: Wrongdoing at the intersection of business and government. New Brunswick: Rutgers.

Kramer, R., Michalowski, R., \& Kauzlarich, D. (2002). The origins and development of the concept and theory of state-corporate crime. Crime and Delinquency, 48(2), 263-282.

Kauzlarich, D., \& Matthews, R. (2006). Taking stock of theory and research. In R. Michalowski \& R. Kramer (Eds.), State-corporate crime: Wrongdoing at the intersection of business and government. New Brunswick: Rutgers.

Lasslett, K. (2010). Scientific method and the crimes of the powerful. Critical Criminology, 18(3), 211-228.

Lasslett, K. (2014). State crime on the margins of empire: Rio Tinto, the war on Bougainville and resistance to mining. London: Pluto.

Marx, K. (1993[1857]). Grundrisse: Foundations of the critique of political economy. London: Penguin.

Matthews, R. (2006). Ordinary Business in Nazi Germany. In R. Michalowski \& R. Kramer (Eds.), StateCorporate Crime: Wrongdoing at the intersection of business and government. New Brunswick: Rutgers.

Matthews, R., \& Kauzlarich, D. (2000). The crash of valujet flight 592: A case study in state-corporate crime. Sociological Focus, 33(3), 281-298.

Naucher. (2013). El proceso del 'Prestige'. Once años a la deriva. www.naucher.com.

Pawiro, S. (2010). Bivalves: Global production and trade trends. In G. Rees, K. Pond, D. Kay, J. Bartram, \& J. Santo Domingo (Eds.), Safe management of shellfish and harvest waters. London: IWA.

Pearce, F. (1976). Crimes of the powerful: Marxism, crime and deviance. London: Pluto.

Pearse, P., \& Walters, C. (1992). Harvesting regulation under quota management systems for ocean fisheries: Decision making in the face of natural variability, weak information, risks and conflicting incentives. Marine Policy, 16(3), 167-182. 
Prada, A., Varela Uña, M., \& Vazquez, M. J. (2002). Dos preguntas sobre el caso 'Prestige'. El País, 7th December 2002.

Rothe, D. (2006). Iraq and Halliburton. In R. Michalowski \& R. Kramer (Eds.), State-corporate crime: Wrongdoing at the intersection of business and government. New Brunswick: Rutgers.

Ruggiero, V. (2013). The crimes of the economy: A criminological analysis of economic thought. London: Routledge.

Surís, J., \& Garza, M. D. (2003). Evaluation of direct and indirect damages. Methodology and work programme for the Prestige case. In A. Prada \& M. J. Vazquez (Eds.), Economic, social, and environmental effects of the 'Prestige' spill. Santiago de Compostela: Consello da Cultura Galego.

Tombs, S. (2012). State-corporate symbiosis in the production of crime and harm. State Crime, 1(2), 170-195.

Tombs, S., \& Whyte, D. (2015). The corporate criminal. London: Routledge.

Varela Lafuente, M., Garza, D., \& Prada, A. (2003). Impactos económicos del vertido. In Ernesto Sánchez (Ed.), La Huella del Fuel. A Coruña: Fundación Santiago Rey.

Walklate, S. (2003). Understanding criminology: Current theoretical debates (2nd ed.). Buckingham: Open University Press.

Whyte, D. (2007). The crimes of neo-liberal rule in occupied Iraq. British Journal of Criminology, 47(2), 177-195.

Whyte, D. (2009). Crimes of the powerful: A reader. Maidenhead: Open University Press.

Whyte, D. (2014). Regimes of permission and state-corporate crime. State Crime Journal, 3(2), 237-246.

Wonders, N., \& Danner, M. (2006). Globalization, state-corporate crime, and women. In R. Michalowski \& R. Kramer (Eds.), State-corporate crime: Wrongdoing at the intersection of business and government. New Brunswick: Rutgers.

\section{Cases}

Reino de España v. American Bureau of Shipping, United States Court of Appeals for the Second Circuit, No. 10-3518-cv.

Spain. Provincial Audience (Section 1). Sentence num. 2641/2013 13th November.

Spain. Supreme Court (Room II). Sentence num. 11/2016 14th January. 